\section{B A Institute of \\ YK Business Administration \\ TK \\ Karachi \\ Leadership and Ideas for Tomorrow}

Business Review

Volume 3 Issue 2 July-December 2008

$7-1-2008$

\title{
The implementation of trademark law in Small and Medium Size Enterprises (SME) business activities in Indonesia
}

Alexander Y Agung Nugroh

School of Business Administration

Sih Yuliana Wahyuningtyas

Atma Jaya Catholic University, Jakarta, Indonesia

Follow this and additional works at: https://ir.iba.edu.pk/businessreview

Part of the Entrepreneurial and Small Business Operations Commons

cc) (i)

This work is licensed under a Creative Commons Attribution 4.0 International License.

\section{Recommended Citation}

Nugroh, A. Y., \& Wahyuningtyas, S. Y. (2008). The implementation of trademark law in Small and Medium Size Enterprises (SME) business activities in Indonesia. Business Review, 3(2), 1-25. Retrieved from https://doi.org/10.54784/1990-6587.1152

This article is brought to you by iRepository for open access under the Creative Commons Attribution 4.0 License and is available at https://ir.iba.edu.pk/businessreview/vol3/iss2/6. For more information, please contact irepository@iba.edu.pk. 


\title{
ARTICLE
}

\section{The Implementation of Trademark Law in Small and Medium Size Enterprises (Sme) Business Activities in Indonesia}

\author{
Alexander Y Agung Nugroh \\ Sih Yuliana Wahyuningtyas \\ School of Business Administration \\ Atma Jaya Catholic University, Jakarta, Indonesia
}

\begin{abstract}
Tn the aftermath of SME and the bigger enterprises in Indonesia, there emerges a

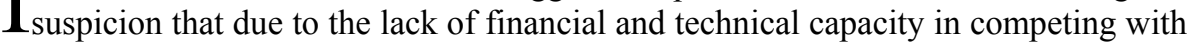
the bigger enterprises, SME conducts various violation of trademark law. Now, the essence of trademark protection is at stake, along with the struggle for SME's life. The challenge for the future will be ensuring greater harmonization of the protection for SME and at the same time, also for trademark. This paper examines the prominent roles of trademark law in dealing business and its implementation by SME.
\end{abstract}

Keywords: small medium sized enterprise, trademark law, business activities

\section{INTRODUCTION}

Fair competition is an unavoidable requirement for global trade, within which not only inventions will be encouraged and protected but also the values of mark of goods or services will be more appreciated with certain price. Trademark, which marks the product to distinguish it from other product, gives benefit to the holder to make sure that the market will be able to recognize the product they have been produced with certain qualities without having to be troubled in distinguishing it and being falsified with other, especially similar, product.

Mark (further: trademark) according to Indonesian Trademark Law can be described as a sign in the form of a picture, name, word, letters, figure, composition of colours, or a combination of said elements, having distinguishing features and used in the activities of trade in goods or services.

Tracing back to the history, trademark in traditional trade is the main means used by merchants to penetrate the chain of grocer and retail trade. This will be further used to set up a direct line to their retail consumers. The use of trademark has been nowadays developed in such way, that it has the function also to determine the value of their products. It is not only goods or the services themselves having value, but trademark has been recognized as reflecting the value and at the same time 
establishing the value of a good or service. Trademark has its own value, which is sometimes higher than the product being presented; so that, for example, even with the same quality and style of jeans, consumers would not regard other jeans with the same value with Levi's. On the other hand, in many cases in Indonesia consumers buy a jeans not because of the quality and style (the intrinsic value), but more because the jeans is Levi's.

Trademark is an exclusive right granted by State to the owner of the mark registered on the Trademark Public Registration for certain period of time to be used or to be licensed to be used by other parties. The law products: trademark, has been constructed to provide legal protection not only for the manufacturers but also for the market, since they have the right to get original products, without being prejudiced with false products even at lower price, and these have been put into common agreement between countries. Those agreements show the same perspective in seeing unfair competition as common problem to deal with. The Paris Convention for the Protection of Industrial Property and The General Agreement on Tariffs and Trade in Annex C on Trade Related Aspects to the Intellectual Property Rights, also the Trademark Law Treaty of 1994 has put this matter in the regulation.

In trade liberalization era, the obedience to these agreements is critically important, since it establishes safety for business players, makes them sure that everything they pay are things as they see when they agree to close the dealings. In short, in the era of global and free trade and in conformity with international conventions having been ratified by the Government of the Republic of Indonesia, the role of trademark becomes significantly important in protecting industrial rights in intellectual works, maintaining fair competition, and encouraging fair and free trade. Indonesia has reflected part of its compliance to the international regulations in regulating trademarks in The Law Number 15 of 2001 of Trademarks.

Law was constructed to be implemented; this is what law enforcement about. But, in fact, there is a kind of missing link to connect the law with its implementation. The problems might be tracked down to the alienation of the law from the society. Small and medium sized enterprises (SME) have revealed sustainability in entrepreneurship when the economic of the country collapses. Unfortunately, they are also becoming marginalized in ways that they enjoy least benefit of economic development, apart from their role in sustaining it. For small and medium size enterprises, thus, the problems are not that simple as the upper middle size has, since law takes price they cannot afford or that is too much to afford and also takes the product into higher price that will cost in loosing certain number of potential market. Violating other's trademark (particularly well-known trademark), then, has been seen as a way of cutting short the problems and it seems understandable, though not acceptable.

Small capital is one of indication in identifying an SME. In Indonesia, this small and medium capital scale of enterprises also brings impact to certain defects needed to 
win the competition with bigger capital enterprise. The shortcomings are, i.a. the lack of capacity to make invention, the limited capacity in production and marketing the products, the inability to fulfil standard of packaging and, suspected also, of product quality (e.g. hygienist ingredients, dyestuff, and expiration date on food products).

With regard to trademark law, SME will be analysed in three points, first, the small number of SME who register their trademark and therefore more numbers gain no protection from the law. Second, there emerges suspicion that in certain kind of products, the certain numbers of SME tend to violate well known trademark, e.g. in foods and drinks, clothing, shoes, and bag products. Third, there is also possibility for SME trademark to be violated by bigger enterprises. The three problems will be described below to find out the background and the needs to restore the law enforcement and at the same time put careful consideration on typical characteristic of SME, bearing in mind that nothing in the RI Trademark Law puts distinction between trademark law for SME and for non SME.

\section{THE LANDSCAPE INDONESIAN TRADEMARK LAW}

\section{DEFINITION AND SCOPE OF TRADE MARK}

Trademark has been widely recognized as part of the intellectual property rights (IPR), a system conceding appreciation and protection to inventor, designer, author or writer, and any other creator or owner of intellectual property. IPR includes not only the private or moral rights but also the economic rights. The system of IPR can be categorized into two major fields as followed:

1. Industrial property, which includes patent, trademark, industrial design, integrated circuit, trade secret and plant variety protection (PVT)

2. Copyright which includes copyright and related rights.

Why shall we protect IPR? Among others, the reasons are: first, based on the Human Rights Declaration, every human being has the right to protection (morally and materially) of their scientific invention, literature or arts as author; second, to protect reputation; third, to encourage and appreciate every innovation and creation; fourth, to prevent the act of reinventing the wheel, and to support research and development.

In Indonesia IPR is protected under several regulations. Such regulations are part of main regulation on competition, which can be divided into three following kind majors: first, unfair business or trade also refers to as act against the law (Civil Law Codification Art. 1365); second, IPR infringement (all IPR regulation); and three, monopoly practices and unfair business competition (Law Number 5 of 1999).

Trademark has been regulated in The Law of the Republic of Indonesia Number 15 of 2001 regarding Trademark (referred herewith as RI Trademark Law). One 
particular importance considered in the Law is that in the era of global trade and in line with the international conventions that have been ratified by Indonesia, the role of mark become more important, particularly in safeguarding a fair business competition.

The responsibility to assure the enforcement of trademark protection in Indonesia is on behalf Directorate General of Intellectual Property Rights (DGIPR- referred as Directorate General). The institution is under Department presided by the Ministry of Justice and Human Rights of the Republic of Indonesia.

With regard to international conventions concerning Intellectual Property Rights (IPR) and in particular, concerning Trademark, Indonesian government has ratified conventions below:

1. Agreement Establishing the World Trade Organization, Annex 1C TradeRelated Aspects of Intellectual Property Rights (TRIPs) by the Law of the Republic of Indonesia Number 7 of 1994 concerning Ratification of Agreement Establishing the World Trade Organization

2. Paris Convention for the Protection of Industrial Property and Convention Establishing the World Intellectual property Rights Organization (WIPO) by Presidential Decree Number 15 of 1997 concerning the Amendment of Presidential Decree Number 24 of 1979

3. Trademark Law Treaty by Presidential Decree Number 17 of 1997

From the above definition of trademark, several basic elements of trademarks can be concluded as follow: 1) mark is a sign, 2) it has distinction power, and 3) used in trade of goods and/or services. Infringement of trademark usually lessens or even deprives the distinction power of the mark infringed, so that the mark loses its function. The sign itself can be in the form of either: 1) picture, 2) name, 3) word, 4) letters, 5) figures, 6) composition of colours, or 7) combination thereof.

The acknowledgment by State on a mark possessed by a person or a legal entity is granted in the form of an exclusive right to himself use the mark or to grant permission to another party to use it. RI Trademark Law Art. 3 rules:

"The right to a mark is the exclusive right granted by the State to the owner of a mark which is registered in the General Register of marks for a certain period of time, to himself use said mark or to grant permission to another party to use it."

Concerning "permission" RI Trademark Law Rt. 1 par. 13 rules:

"License shall mean a permission granted by the owner of a registered mark to another party by means of an agreement based on the grant of right (not the transfer of right), to use the relevant mark, either for all or some of the 
kinds of goods and/or services that are registered for a certain of period of time and certain requirements."

The exclusive right granted by the act of registration. The right is not obtained at the time the said mark is invented or used, but the time when it is registered. This system of registration is acknowledged as constitutive system, in which registration become absolute mandatory to obtain the exclusive right - which means also legal protection.

Such system can be compared with the other system recognized by jurists in IPR registration system; that is declarative system. In this system, registration plays function only as evidence that the registrant is the first user of the said mark. This kind of registration does not raise a right; it provides only legal assumption (rechtsvermoeden) or presumption iuris that the party whose mark is registered is the most entitled to and as the first user of the said mark.

In contradiction to the former Law, the latest RI Trademark Law applies the constitutive system instead of the declarative. The aim is to ensure legal assurance for the mark owner.

There are negative qualifications which enable the mark not to be registered. The qualifications are ruled in Art. 4 and 5 of the RI Trademark Law as such:

concerning the applicant (Art. 4): a mark shall not be registered on the basis of an application by an applicant having bad faith.

concerning the mark itself (Art. 5): a mark shall not be registered if it contains one of the following elements: a) contradicting with the prevailing rules and regulation, morality of religion, or public order; b) having no distinguishing features; c) having become public property; or d) constituting information or related to the goods or services for which registration is requested.

RI Trademark Law also puts another negative qualification that shall result in refuse on the part of the Directorate General, according to Art 6 par. (1) of the RI Trademark Law, when the mark in question:

a. has a similarity in its essential part or in its entirety with a mark owned by another party which has previously been registered for the same kind of goods and/or services;

b. has a similarity in its essential part or in its entirety with a well-known mark owned by another party for the same kind of goods and/or services;

c. has a similarity in its essential part or in its entirety with a known geographical indication.

Further in Art. 6 par. (3) an application for registration of a mark shall also be refused by the Directorate General if: 
a. it constitutes or resembles with the name of a famous person, photograph, or the name of a legal entity belonging to another party, except with a written consent of the entitled party;

b. it constitutes an imitation or resembles with a name or abbreviation of a name, flag or coat of arms or a symbol, or an emblem of a state, or of a national or international institution, except with a written consent of the competent authority;

c. it constitutes an imitation or resembles with an official sign or seal or stamp used by a state or a government institution, except with a written consent of the competent authority.

In conclusion, to acquire legal protection under RI Trademark Law by means of registration, a mark shall meet the following requirements: 1) the said mark is a sign having distinction power of goods or services; 2) being used in trade; and 3) not fulfil either of Art. 4, 5 and 6 of the Trademark Law.

\section{PROCEDURE OF REGISTRATION}

Prior to registration, the applicant shall file an application in writing in the Indonesian language at the Directorate General. The application shall be signed by the applicant or his proxy. An application that is filed by an applicant who resides or permanently domiciles outside the territory of the Republic of Indonesia must be filed through a proxy in Indonesia and shall state and choose the address of his proxy as his legal address in Indonesia.

RI Trademark Law also recognizes priority right, which according to Art. 1 par. 14 is defined as right of an applicant to file an application originating from a member country of the Paris Convention for the Protection of Industrial Property or the Agreement Establishing the World Trade Organization (WTO) in order to get recognition that the filing date of the country of origin be the priority date in the country of designation that is also a member country of the two agreements, provided that the filing date of the application is made during the period prescribed in the Paris Convention for the Protection of Industrial Property. Furthermore, Art. 11 rules that an application with a priority right shall be filed within a period of 6 months at the latest, commencing from the first filing date of the application in another country, which is a member of the Paris Convention for the Protection of Industrial Property or a member of the WTO.

Art. 7-12 of RI Trademark Law provides all administrative requirements to file an application. Where all administrative requirements have been fulfilled, the applicant shall be given a filing date which shall be recorded by the Directorate General. The application can be amended, nevertheless such amendment shall only be allowed for the change of name and/or address of the applicant or his proxy. It also can be 
withdrawn by the applicant or his proxy, under circumstances that such application has not been decided by the Directorate General.

The procedure of registration is as followed:

Examination: the Directorate General shall conduct a substantive examination of an application with due regard to the provision of Art. 4-6 of RI Trademark Law within the period of 30 days at the latest from the filing date. The substantive examination shall be conducted by the examiner at the Directorate General. (Art. 18, 19)

\section{ANNOUNCEMENT OF THE RESULT OF EXAMINATION}

a. In case of approval: where the examiner concludes the result of the substantive examination that an applicant can be approved for registration, the Directorate General with the approval of the Director General shall announce the application in the Official Gazette of Marks within 10 days and the announcement shall last for 3 months. (Art. 20 par. [1], Art. 21, and 22)

b. In case of refusal: here the Examiner concludes the result of the substantive examination that an application cannot be registered or shall be refused, the Directorate General with the approval of the Director General shall notify in writing the applicant or his proxy stating the reasons therefore. (Art. 20 par. [2]) Within 30 days at the latest from the date of receipt of the notification, the applicant or his proxy may submit an objection or a comment, stating the reasons therefore. (Art. 20 par. [3]) Unless the Directorate General shall decide on the refusal of the application. (Art. 20 par. [4]) Where the applicant or his proxy submits the above objection (Art. 20 par. [3]) and the Examiner concludes that such objection or comment can be accepted, the Directorate General with the approval of the Director General shall announce the relevant application in the Official Gazette of Marks. (Art. 20 par. [5]) Where the Examiner concludes that such objection or comment cannot be accepted, the Directorate General with the approval of the Director General shall decide on the refusal of the application. (Art. 20 par. [6])

\section{OBJECTION, REBUTTAL, AND RE-EXAMINATION}

a. Objection: during the period of the above announcement (point 2.a.), any person or legal entity may file an objection to an application, in writing to the Directorate General, where there is sufficient reason accompanied by evidence that the mark for which registration is requested is a mark, which under RI Trademark Law shall not be registered or shall be refused. In such case, the Directorate General shall within 14 days at the latest from the date 
of receipt of the objection send a copy of the letter containing said objections to the applicant or his proxy. (Art. 24 par. [1]-[3])

b. Rebuttal: the applicant or his proxy shall be entitled to file a rebuttal to such objection at the Directorate General in writing within 2 months at the latest from the date of receipt of the copy of the objection sent by the Directorate General. (Art. 25 par. [1] and [2])

c. Re-examination: in the case of objection and/or comment, the Directorate General shall use that objection and rebuttal as material to be considered in the re-examination of the application that has been announced (point 2.a.), which shall be completed within 2 months from the date of expiry of the announcement and the Directorate General shall notify the result in writing to the party having filed the objection. Where the examiner concludes that the objection can be accepted, the Directorate General shall notify the applicant on writing that the application cannot be registered or is refused; and in such case, the applicant or his proxy may file a request for an appeal petition. Where the objection cannot be accepted, with the approval of the Director General, the application shall be registered in the General Register of Marks. (Art. 26 par. [1]-[5])

\section{CERTIFICATE OF MARK}

a. In case there is no objection: where there are no objections as referred to in point 3.a., the Directorate General shall issue and grant a Mark Certificate to the applicant or his proxy within 30 days at the latest from the date of expiry of the announcement period. (Art. 27 par. [1])

b. In case an objection cannot be accepted: in the case that an objection cannot be accepted as referred to in point 3.c., the Directorate General shall issue and grant a Mark Certificate to the applicant or his proxy within 30 days at the latest commencing from the date the relevant application was approved for registration in the General Register of Marks. (Art. 27 par. [2])

c. Content of Mark Certificate: the Mark Certificate shall contain: 1) the full name and address of the owner of registered mark; 2) the full name and address of the proxy, where the application is filed based in Art. 10;3) the date of application and date of filing; 4) the name of country of and the first filing date, where the application is filed with the priority rights; 5) the specimen of registered mark, including the illustration of the colours of the mark uses colour elements, and if the mark uses a foreign language and/or letters other than Latin and/or figures that are not commonly used in the Indonesian language, it shall be furnished with the translation in the Indonesian language, Latin letters and figures that are commonly used in the Indonesian language, and the spelling in Latin; 6) number and date of registration; 7) class and type of goods and/or services of the registered mark; and 8) period of validity of the mark registration. (Art. 27 par. [3]) 


\section{APPEAL PETITIONS}

a. Filing an appeal petition: a petition for appeal may be filed against the refusal of an application on the grounds of substantive matters as referred to in Art. 4-6 within 3 months from the date of notification of refusal of the application. The petition shall be filed by the applicant or his proxy to the Trademark Appeal Commission in writing and a copy thereof shall be sent to the Directorate General, with a payment fee. Such appeal petition shall describe in detail the objection to the refusal of the applicant as the result of the substantive examination and the ground must not constitute corrections or completions of the refused application. (Art. 29 par. [1]-[4] and Art. 30 [1])

b. The decision of the Trademark Appeal Commission: such decision shall be made within 3 months at the latest commencing from the date of receipt of the appeal petition. In the event the Trademark Appeal Commission approves the appeal petition, the Directorate General shall conduct the announcement as referred to in point 2.a. except for application that have already been announced in the General Register of Marks as referred to in point 3.c. (Art. 32 par. [2])

c. The Commercial Court: in the event the Trademark Appeal Commission refuses the appeal petition, the applicant or his proxy may bring an action to the Commercial Court within 3 months at the latest from the date of receipt of the refusal. (Art. 32 par. [3])

d. Cassation: upon the decision of the Commercial Court, may only b filed a cassation. (Art. 32 par. [4])

\section{PERIOD OF PROTECTION OF REGISTERED MARK AND THE EXTENSION}

a. Period of protection and the extension: a registered mark shall have legal protection for 10 years from the filing date and the protection period can be extended under request of the owner of the registered mark for the same duration. (Art. 28 and 35 par. [1])

b. Requirement of extension: a request for the extension shall be approved if: 1) the relevant mark is still used on the goods or services as stated in the Mark Certificate, and 2) the goods or services as referred to in point 1) are still produced and traded. (Art. 36) 


\section{CHANGE OF NAME AND/OR ADDRESS OF A REGISTERED MARK OWNER}

a request for the change of name and/or address of a registered mark owner to be recorded in the General Register of Marks shall be filed at the Directorate General, with a payment of fee and accompanied by a valid copy of the evidence of said change and upon registered in the General Register of Marks shall be announced in the Official Gazette of Marks. (Art. 39 par. [1]-[2])

\section{DELETION AND CANCELLATION OF REGISTRATION OF A MARK}

a. Deletion of a mark: the deletion of a mark registration may be made by the Directorate General either at its own or at request of the owner of the mark concerned. The deletion of a mark registration on the initiative of the Directorate General may be made if: 1) the mark has not been used for 3 consecutive years in trade of goods and/or services from the date of registration or of the last use, except there is an excuse which is acceptable to the Directorate General; or 2) the mark is used for the kind of goods and/or services which is not in pursuant to the kind of goods and/or service for the mark application for registration was filed, including the use of mark which is not in accordance with the registered mark. (Art. 61 par. [1]-[2]) Any third party shall also be able to file a request for the deletion of the registration of a mark on the grounds a referred in 2) in the form of a claim filed at the Commercial Court. Upon the decision of the Commercial Court can only be filed a cassation. (Art. 63 and 64 par. [1])

b. Cancellation: a lawsuit for the cancellation of a registered mark may be filed by any interested party based on the grounds as referred to in Art. 4-6. An owner of unregistered mark may file such lawsuit after filing an application at the Directorate General. The lawsuit for cancellation shall be filed at the Commercial Court within 5 years after the date of mark registration. Upon the decision of the Commercial Court may only be filed a cassation.

Fees: a fee, the amount of which shall be regulated by Government Regulation, shall be paid upon the filing of an application or a request for the renewal of a mark, a request for excerpt of the General Register of Marks, a request for the recording of the transfer of right, a request for recording the changes of name and/or address of owner of a registered mark, a request for the recording of a licensing agreement, a request for the objection on an application, a request for an appeal petition, and other matters regulated in the RI Trademark Law. (Art. 75 par. [1]) In general, the following table shows the fee of registration procedure. 
Table 1: Fees of Trademark

\begin{tabular}{|c|c|c|c|c|c|}
\hline No. & \multicolumn{2}{|r|}{ State Revenue Excluding Tax } & Remark & & Fee \\
\hline \multirow[t]{6}{*}{1.} & \multicolumn{5}{|c|}{$\begin{array}{l}\text { Fee of Trademark registration application and request for extension period } \\
\text { of trademark registered protection : }\end{array}$} \\
\hline & a. & $\begin{array}{l}\text { Application for registration of Trademark } \\
\text { and Service Mark }\end{array}$ & $\mid$\begin{tabular}{||l||} 
Per \\
application
\end{tabular} & $\operatorname{Rp}$ & $450.000,00$ \\
\hline & b. & $\begin{array}{l}\text { Application for registration of } \\
\text { Geographical Indication }\end{array}$ & $\begin{array}{l}\text { Per } \\
\text { application }\end{array}$ & $\mathrm{Rp}$ & $250.000,00$ \\
\hline & c. & $\begin{array}{l}\text { Application for registration of Collective } \\
\text { Mark }\end{array}$ & \begin{tabular}{|l||} 
Per \\
application
\end{tabular} & $\operatorname{Rp}$ & $600.000,00$ \\
\hline & d. & $\begin{array}{l}\text { Application for extension period of } \\
\text { Trademark protection }\end{array}$ & $\|$\begin{tabular}{l||} 
Per \\
application
\end{tabular} & $\mathrm{Rp}$ & $600.000,00$ \\
\hline & e. & $\begin{array}{l}\text { Application for extension period of } \\
\text { Collective Mark protection }\end{array}$ & $\begin{array}{l}\text { Per } \\
\text { application }\end{array}$ & $\operatorname{Rp}$ & $750.000,00$ \\
\hline \multirow[t]{8}{*}{2.} & \multicolumn{5}{|c|}{ Fee for recordation in the General Ristration List of Trademark : } \\
\hline & a. & $\begin{array}{l}\text { Recordation of changing name and or } \\
\text { address of the trademark owner }\end{array}$ & Per & $\mathrm{Rp}$ & $150.000,00$ \\
\hline & b. & $\begin{array}{l}\text { Recordation of transferring Rights on } \\
\text { registered trademark }\end{array}$ & Per & $\mathrm{Rp}$ & $375.000,00$ \\
\hline & c. & Recordation of License Agreement & \begin{tabular}{|l||} 
Per \\
application
\end{tabular} & $\operatorname{Rp}$ & $375.000,00$ \\
\hline & d. & $\begin{array}{l}\text { Recordation of removing of trademark } \\
\text { registration }\end{array}$ & \begin{tabular}{|l||} 
Per \\
application
\end{tabular} & $\mathrm{Rp}$ & $150.000,00$ \\
\hline & e. & $\begin{array}{l}\text { Recordation of changing regulation of } \\
\text { Collective Mark usage. }\end{array}$ & $\begin{array}{l}\text { Per } \\
\text { application }\end{array}$ & $\mathrm{Rp}$ & $225.000,00$ \\
\hline & f. & $\begin{array}{l}\text { Recordation of transferring Rights on } \\
\text { registered collective mark }\end{array}$ & \begin{tabular}{l||} 
Per \\
application
\end{tabular} & $\mathrm{Rp}$ & $450.000,00$ \\
\hline & g. & $\begin{array}{l}\text { Recordation of removing the registered } \\
\text { collective mark }\end{array}$ & \begin{tabular}{|l||} 
Per \\
application
\end{tabular} & $\mathrm{Rp}$ & $225.000,00$ \\
\hline \multirow[t]{2}{*}{3.} & \multicolumn{5}{|c|}{$\begin{array}{l}\text { Fee for request of official copy and written notification concerning } \\
\text { Trademark : }\end{array}$} \\
\hline & a. & $\begin{array}{l}\text { Request for official copy of trademark } \\
\text { registration }\end{array}$ & $\begin{array}{l}\text { Per } \\
\text { application }\end{array}$ & $\mathrm{Rp}$ & $75.000,00$ \\
\hline
\end{tabular}




\begin{tabular}{||l||l|l|l||r||}
\hline & $\begin{array}{l}\text { b. } \\
\text { Request for written notification } \\
\text { concerning General List of trademark }\end{array}$ & $\begin{array}{l}\text { Per } \\
\text { application }\end{array}$ & Rp & $125.000,00$ \\
\hline $\begin{array}{c}\text { c. } \\
\text { Request for written notification } \\
\text { concerning the declaration between the } \\
\text { trademark which has similarity in its } \\
\text { essential part to another trademark which } \\
\text { has been registered }\end{array}$ & $\begin{array}{l}\text { Per } \\
\text { application }\end{array}$ & $\mathrm{Rp}$ & $125.000,00$ \\
\hline 4. & Fee for Trademark Appeal request & $\begin{array}{l}\text { Per } \\
\text { application }\end{array}$ & $\mathrm{Rp}$ & $1.000 .000,00$ \\
\hline 5. & $\begin{array}{l}\text { Fee for Geographical Indication Appeal } \\
\text { request }\end{array}$ & $\begin{array}{l}\text { Per } \\
\text { application }\end{array}$ & $\mathrm{Rp}$ & $1.000 .000,00$ \\
\hline \hline 6. & $\begin{array}{l}\text { Fee for opposition on Trademark registration } \\
\text { application }\end{array}$ & $\begin{array}{l}\text { Per } \\
\text { application }\end{array}$ & $\mathrm{Rp}$ & $100.000,00$ \\
\hline 7. & $\begin{array}{l}\text { Fee for request of official copy of } \\
\text { Geographical Indication registration }\end{array}$ & $\begin{array}{l}\text { Per } \\
\text { application }\end{array}$ & $\mathrm{Rp}$ & $50.000,00$ \\
\hline 8. & $\begin{array}{l}\text { Fee for copy of priority proven on trademark } \\
\text { application }\end{array}$ & $\begin{array}{l}\text { Per } \\
\text { application }\end{array}$ & $\mathrm{Rp}$ & $50.000,00$ \\
\hline
\end{tabular}

\section{TRADEMARK VIOLATION}

RI Trademark Law does not explicitly rule the definition and forms of trademark violation. Nevertheless, the concepts are implied in Art. 76 par. (1) of RI Trademark Law concerning settlement of disputes as followed:

"The owner of a registered mark may file a lawsuit against any other party that unlawfully uses his mark for goods and/or services which has similarity in its essential part or its entirety with his mark, in the term of:

a. claim for compensation, and/or

b. the termination of all acts that are related with the use of the relevant mark."

Accordingly, we can arrive to a logical conclusion that trademark violation is an unlawful use of mark which has similarity in its essential part or its entirety with other party's mark.

We can also take conclusion from the criminal provision in Chapter XIV, that trademark violation includes: 1) deliberate and unlawful use of a mark which has similarity in its entirety to a registered mark of another party for the same kind of goods and/or services produced and/or traded (art. 90); 2) deliberate and unlawful use of a mark which has similarity in its essential part a registered mark of another party for the same kind of goods and/or services produced and/or traded (Art. 91); and 3) trade of goods and/or services that are known or shall be known that the goods and/or services resulted from the infringement (Art. 94). 


\section{SME DEVELOPMENT IN INDONESIA}

\section{DEFINITION OF SME}

There have been several attempts to formulate an accurate definition of SME. SME in Indonesia has been regulated in the Law of the Republic of Indonesia Number 9 of 1995 Concerning Small Enterprises (referred as SME Law). Small enterprise in Art. 1 par. 1 is defined as people economic activity having small scale and shall meet the criteria of capital or annual sales and ownership as regulated in the Law. Art. 1 par. 2 defines medium and big enterprise as economic activity having bigger net capital criteria or annual selling profit in comparison with small enterprises.

The criteria for small enterprise according to Art. 5 par. (1) are:

a. has net capital no more than Rp 200.000.000, including land and building for the business, or

b. has annual selling profit no more than $\mathrm{Rp} 1.000 .000 .000$

c. belongs to Indonesian citizens

d. independent, not as subsidiary or branch of a company owned, controlled by, or affiliated directly or indirectly with medium or big enterprise;

e. owned by one person, business enterprise having "non legal" or "legal" entity including cooperative.

Table 2 below shows the number of non-legal entities according to the business sector and number of workers.

Table 2. The Number of Non-Legal Entities according to the Business Sector and Number of Workers

\begin{tabular}{|l|c|c|c|c|c|c|c|}
\hline \multicolumn{1}{|c|}{$\begin{array}{c}\text { Business sector/ } \\
\text { Lapangan usaha }\end{array}$} & \multicolumn{5}{|c|}{ Number of workers/Jumlah pekerja } & \multirow{2}{*}{ Total/Jumlah } \\
\cline { 2 - 7 } & $\mathbf{1}$ & $\mathbf{2 - 4}$ & $\mathbf{5 - 9}$ & $\mathbf{1 0 - 1 4}$ & $\mathbf{1 5 - 1 9}$ & $\mathbf{2 0 +}$ & \\
\hline $\begin{array}{l}\text { Small-scaled mining and } \\
\text { quarrying, non-PLN electricity } \\
\text { and construction/ Pertambangan } \\
\text { rakyat dan penggalian listrik } \\
\text { non PLN dan konstruksi }\end{array}$ & 123,103 & 133,311 & 23,342 & 7,084 & 690 & 127 & 287657 \\
\hline $\begin{array}{l}\text { Small and home } \\
\text { industries/Industri kecil dan } \\
\text { kerajinan rumah tangga }\end{array}$ & 902,919 & $1,404,643$ & 184,614 & 29,813 & 15,115 & 1,179 & $2,538,283$ \\
\hline $\begin{array}{l}\text { Wholesale, retail, restaurants } \\
\text { and accomodation/ } \\
\text { Perdagangan besar, eceran, dan } \\
\text { rumah makan serta jasa } \\
\text { akomodasi }\end{array}$ & $3,961,547$ & $4,251,814$ & 201,494 & 24,540 & 3,375 & 7,441 & $8,450,211$ \\
\hline
\end{tabular}




\begin{tabular}{|l|c|c|c|c|c|c|c|}
\hline & & & & & & & \\
\hline $\begin{array}{l}\text { Transport and } \\
\text { kommunications/Angkutan dan } \\
\text { komunikasi }\end{array}$ & $1,472,570$ & 281,301 & 9,528 & 1,340 & 213 & 98 & $1,765,050$ \\
\hline $\begin{array}{l}\text { Finance institutions, real estate, } \\
\text { rental and service } \\
\text { business/Lembaga keuangan, } \\
\text { real estate, usaha persewaan, } \\
\text { dan jasa-jasa }\end{array}$ & 984,271 & 579,600 & 46,344 & 5,784 & 1,564 & 1,881 & $1,619,444$ \\
\hline Total & $\mathbf{7 , 4 4 4 , 4 1 0}$ & $\mathbf{6 , 6 5 0 , 6 6 9}$ & $\mathbf{4 6 5 , 3 2 2}$ & $\mathbf{1 , 5 6 4}$ & $\mathbf{2 0 , 9 5 7}$ & $\mathbf{1 0 , 7 2 6}$ & $\mathbf{1 4 , 6 6 0 , 6 4 5}$ \\
\hline
\end{tabular}

Statistics Indonesia provides a definition based upon the number of workers in order to determine the size of business, particularly in the manufacturing sector, i.e.: a handicraft home industry employs 1-4 workers, and a small industry employs 5-19 workers, including the owner.

The same definition is also used by the Ministry of Industry and Trade in differentiating between business, i.e.: micro-trading business (1-4 workers), small trading business (5-19 workers), medium-sized trading business (20-99 workers), and big trading business (more than 100 workers). Another criterion is that the annual turnover of less than Rp 1 billion (also used by the Ministry of Industry and Trade).

\section{SME DEVELOPMENT}

From the point of view of developing countries, the value of SME can be analysed in both static and dynamic terms. In static terms, the value of SME is assessed according to its productivity and employment-generating. Taking into account total factors of productivity including capital, SME attains better productivity than microenterprise, and in terms of employment it creates better employment than large enterprise. ${ }^{i}$ The SME contribution in providing employment has become a particular feature of developing countries, which on one side indicating the working market, that more people are empowered and encouraged to take part to make best use of possible economic factors for the community. On the other side it shows economic failure to provide people with productive jobs and forced people to pursue their part in economics with less possibility to survive.

According to its dynamic terms, SME is analyzed according to its potential of growth. In most cases, SME tends to grow notably, but this growth will not result in exiting the category of SME. This can explain how the size of SME is getting bigger over time, though the growth within the category is very dynamic. 
Statistic Indonesia 1998 shows the percentages of SME in Indonesia. Among 39.8 million enterprises in Indonesia, 99.8\% are small enterprises and the rest 0.2 are medium and big enterprises. According to business volume, 99.85\% enterprise have business volume of under 1 billion (absorbing $88.66 \%$ of labour), $0.14 \%$ occupy 1 50 billion (absorbing $10.78 \%$ of labour), and $0.01 \%$ owe 50 billion (absorbing $0.56 \%$ of labour).

Statistics released by Ministry of Cooperative and Small-Medium Enterprise illustrate that in 2000-2003 SME sets $99.9 \%$ (equal to 38,723,987) of the total business unit of $38,725,960$. This number of SME in the same years takes in $99.46 \%$ (equal to $70,407,439$ ) labour of the total of $70,789,877$. SME contributed $54.51 \%$ to the total PDB in 2000 and increased up to $56.73 \%$ in 2003 . SME also took $14.87 \%$ part of the total export in 2002 and increased up to $15.43 \%$ in 2003. Other significant contributions of SME are providing 57\% supply of goods and service and $2-4 \%$ share to national development.

It is pointed out, that though the growth of SME continues steadily; their productivity has to be analyzed separately. Investment and change in technological terms are both at the end the key of the increasing productivity. The problem is, that it is not the case for SME to increase productivity needed through foreign direct investment, technology licensing, joint ventures, access to engineering and other improvements, which are for large enterprise in developing countries not problematic.

Other aspect of the dynamics of SME, which does not take place in bigger enterprises, is their high rate of entry and exit due their fewer requirements of formalities. At the same time this has nevertheless mounted issues on efficiency.

Flexibility is the next point to be apprehended concerning the analyses of SME in compare with bigger enterprises. The argument has been put forward, that this point is considered as an advantage for swiftly changing market of industries and economies. This is the case as well for the sharp downturn of macroeconomics which caused collapses in some East Asian countries during the past few years, e.g the economic crisis in Indonesia during 1997 which brought impact to, among others, GDP growth, import and industrialization policy and open economy strategy, employment and labour productivity.

Concerning manufacturing in the 1990s up until the crisis, SME has paid the cost for the growth of bigger enterprises in some industries, like in bamboo weaving and palm sugar processing. It is not the case in other industries.

Concerning labour productivity is assessed in firm and industry or manufacturing level. At firm level, labour productivity increases due to the augment of capital per 
worker and change in technology. At industry or manufacturing level, reallocation of resources is considered as other factor contributing in boost of labour productivity. In the case of sources of technological capability of exporting SME in rattan furniture, Jepara wood furniture, and garments (three important export industries in which SME play significant roles), Berry and Levy ${ }^{\text {ii }}$ drawn attention to several points:

1. "Private channels have been the dominant mechanism for acquiring such capability in all three sectors;

2. subcontracting is pervasive in all three industries and has been crucial to harnessing traditional skills for export production, especially in Jepara;

3. employment of expatriates is an especially powerful mechanism for acquiring technological capability in the rattan and garment sectors, but this practice is concentrated disproportionately among non-pribumi entrepreneurs who have the advantage of being embedded in an extended (ethnic) community that transcends national boundaries;

4. collective support mechanism (public sector and private association) have played only a limited role overall; they have been more important to the smaller pribumi firms but their overall value has been limited by pervasive institutional weakness."

Indonesia's small industry has contributed in the boom of manufactured export boom of recent years as pointed by Hal Hill, that the absolute level of direct exports rose from US\$ 137 million in 1983 to 2.1 billion in 1992 and as Kian Wie Thee wrote before, its share of such exports increased from 10 to $13.2 \%$, after reaching $17.3 \%$ in 1987. The main items for bigger industry are garments, textiles, and footwear, which altogether amount to $60 \%$, due to the finding slot markets and the adapting costs and quality to market demand. Subcontracting agreements have been used to export fast increasing share of SME outputs.

SME flexibility and related capacity to, for instance, weather storms, shift from product to product, expand and contract easily have become important points to answer question on how SME responded to economic crisis, which enable them to do relatively better under volatile macro conditions than big firms producing more standardized products, where reorganization of the assembly line take time. Lower sunk costs and less frequent labour capital struggles are other sources of flexibility. Nevertheless, the issue being put forward that the first victim of macro economic crises, is worth to be considered due to several reasons. Albert Berry, Edgard Rodriguez, and Henry Sandee explain as followed:

"First, a flexible SME sector, able to adjust smoothly to severe shocks, is clearly a major plus as a country tries to mitigate the effects of those shocks and to avoid large increases on poverty. Also, even if many SME show impressive agility in general, certain types of shocks might destroy firms with good loner run potential, raising the question of what policy 
instruments might help to avoid that outcome. Finally, is to be expected that any given macroeconomic crisis will be affect in different ways, and that appropriate policies to support SME will vary widely according to how those firms are placed in the economy."

In such case as Jepara furniture, the underlined problem is the weakening of local demand. It is best positioned, that industries shall export a lot or competes with imports, but at the same time are not dependent mainly on domestic demand and not competing with imports, and gaining strongly from imports of material or capital goods.

Ministry of Industry is thus the main agent for SME promotion. Up to early 1994 most programs were formulated, monitored, and executed by the Directorate General of Small Industries. The directories in Jakarta handle policy formation, administration, and training of the provincial and regency offices of the ministry. These offices, attached to all Kabupaten (regencies) in the country, are responsible for the executing and monitoring of the programs. Many extension workers are experts in the field of small business development and are well aware of the specific constraints and prospects for local small enterprise, through frequently without the resources to deliver assistance in accord with their ideas. The combination of its being free to the client and the enormous size of the nationwide target group means that this technical (non financial) assistance must be provided at relatively low average cost. Some extension workers have also played successful intermediate role in linking small firms to larger business or the banking sector.

\section{PROSPECT FOR THE IMPLEMENTATION OF TRADEMARK LAW IN SME BUSINESS ACTIVITY IN INDONESIA}

If trademark protection is deemed important and if SME contributes valuable role in Indonesian economic, then why the two of them are quite difficult to come together? When we deal with this issue, focuses will be put on three problems: first, the number of SME registering their trademark. Second, there is suspicion that a certain number of SME tend to violate trademark law. Third, there is possible SME trademark violation by bigger enterprise. The three problems will be analyzed below.

\section{REGISTRATION OF TRADEMARK BY SME}

From the total business unit of 38,725,960 in 2003, only 46.947 filed application of trademark registration, 35.353 of them were registered, 3,527 were refused, and 83 were withdrawn. In general, therefore, only $0.12 \%$ of the total business unit submit their application for trademark registration and only $0.09 \%$ of the total business unit have their trademark actually registered. 
The small percentage of trademark registration might be traced back in the procedure of registration. As briefly above described, trademark registration cost not only sum of money but also length of period that can be considered as obstacle in gaining cheap, practical, and easy registration.

For instance, based on assumption that the process of registration runs well, then the applicant will need to pay the application for registration of trademark + request for written notification concerning General List of trademark $=\mathrm{Rp} 450.000,00+\mathrm{Rp}$ $125.000,00=\operatorname{Rp} 575.000,00$. This amount has not included fee for the proxy, whose service will be needed for those having no experience concerning trademark registration. DGIPR provides "IPR clinic" for SME. The main role of the "IPR clinic" is to serve consultancy for the applicant of trademark registration. The fee for IPR clinic for SME is Rp 600.000,00. Thus, the total amount for trademark registration will be no less than $\mathrm{Rp} 1.175 .000,00$. This number cannot be considered as cheap for SME, in particular when trademark registration has not been considered as necessary or important. The amount will increase due to the Government plan to issue Regulation on IPR Consultant, whose fee is at least five times more expensive than the fee for "IPR clinic".

The problem will be twice folded due to the new Government Regulation No. 2 of 2005 regarding IPR registration, which will be applied in the near future. The new regulation rules that the application of IPR (including trademark) shall be requested directly by the owner or IPR consultant. One of the requirements of IPR consultant is that he or she is not civil servant. This requirement will bring change in way that up to today, IPR clinic of the DG-IPR provides assistance for the registration. The $90 \%$ members of IPR clinic are civil servants. After the implementation of the new regulation, such assistance will be provided by private consultant, who usually charge more expensive fee for such service. For instance, IPR clinic only charge a fee of Rp 600,000,00, but private IPR consultant might charge various amount of fee, usually not less than $\mathrm{Rp} 3,000,000,00$ (that is five times more expensive) for each application.

Regarding the length of period of registration, in case the registration is without refusal and objection, the procedure from the filing date to the announcement of the application in the Official Gazette of Marks will take 310 days (or more then 10 months) at the latest, that is 30 days at the latest from the filing date for the examination up to 270 days (or 9 months) and 10 days at the latest for the announcement. The duration is considered as too long for the procedure, bearing in mind that in some cases there might emerge refusal and objection, which will take longer period.

The combination of high cost and long duration of process results in complicated procedure, so that it is reasonable that it cost hesitation for SME. ${ }^{\text {iii }}$ The hesitation to 
register trademark has hampered the development of the business as witnessed in SME development in West Java. This is the case of Majalaya textile, Majalengka soy sauce, and Cibaduyut shoes. This case illustrates another function of trademark; that is to reflect the commitment to deal in particular business sector in a long term. The lack of awareness on the selling value of a trademark has not only slow down the business, but even resulted in the loss of image when it has to compete with stronger trademark registered. Majalaya textile has started the business far before a well known trademark of traditional product: "Jamu Nyonya Meneer" in 1928 but also never registers the mark. The business has sunk, instead of the stronger image build by Nyonya Meneer from the mark it has registered. 310 Majalengka SME producing soy sauce have claimed their products as number 1 product, but never registered the marks. The business opportunity was taken thereafter by bigger enterprises. There is no trademark violation, but the well known image in the past was taken over by more firm and strong image registered. Nowadays, soy sauce Majalengka only wins the market of traditional meatloaf in Indramayu, Cirebon, and Majalengka region. Cibaduyut as small industry centre for shoes sector has began the business since 1956 and up to 1975, it won the image of quality. Most of the marks of the SME within Cibaduyut center are never registered and after 1975 it began to focus on meeting market demand and neglecting the quality. Up to 1900 only 11 trademarks were registered.

Another case is the registration of trademarks belongs to traditional SME by foreigners. This is the case of Toraja coffee originated from Toraja, South Sulawesi. The trademark was registered lately by Key Coffee from Japan. The case results in the obligation for Indonesian to export Toraja coffee to Japan through Key Coffee.

The main problems for SME to register their trademark are the combination of two or more elements as followed: first, the less awareness of the importance of trademark protection or the assumption that trademark protection is irrelevant or even puts barrier in dealing business. Business dealing requires short, cheap, and practical administrative procedures. In case where the procedure becomes high cost, then the benefit will be reduced. This is not interested in particular for those who are not supported with strong capital to bear the cost. It is not too surprising therefore to reach conclusion that trademark is considered as equal to high cost and complicated.

Second, there is only limited access to get proper information concerning trademark law. This problem arises due to the lack of understanding on the real problem, instead of giving information, which having been known by the target group. Such dissemination of information does not touch the essential function of giving information; that is bringing awareness on the part of SME. Accordingly, a proper research to understand what is needed to be understood by SME with regard to the importance of trademark protection will be deemed necessary. 
Third, the more general yet worse problem is the distrust to national legal system in general and in particular to IPR legal system, that legal protection is equal to big money and big enterprise. There is no guarantee that after fulfilling all the requirements for legal protection, they will be actually protected. The issue of unfair court seems to bring impact the wider scope of law enforcement.

Fourth, in certain level, the behaviour pattern of business actor who less respect invention or the right of inventor of a mark affects the way of thinking on whether such protection is necessary. The problem dealing with here has more closed connection with culture. To acquire proper solution on this matter, it requires careful study on business culture in Indonesia.

\section{TRADEMARK VIOLATION BY SME}

Certain possibility of the trademark violation and thus, bring injury to the original holder can be described as follows: first, the loss or less distinction ability of the mark, which means that the mark becomes loosing its function.

Second, there appears confusion for the consumers to identify the products using original mark and those using the counterfeit mark (though in some cases, the counterfeiting products are sold in much lower price than those of the original with lower quality, that enable the consumers to distinguish it easily with the originals.) Such confusion for various reasons will tend to end up in the consumers failure to relate the products to the owner of the mark. This case falls under the act of misleading or deceiving the consumers.

Third, trademark has selling price and the price is unfairly taken by other parties who at the same time also take over the market of the original marks. In this situation, careful examination has to be taken to conclude whether or not there occurs a different market of the two products, the originals and the counterfeits, due to the different price and purchase power of the consumers. Nevertheless, in spite of the possibility of such assumption, taking benefit of others advantage by illegally overriding the image is regarded as unfair act and violates the exclusive right of trademark holder to use its mark and the image attached to it.

Fourth, in certain cases, it is possible that illegal use of others trademark will cause the failure for the consumers to associate the quality of counterfeiting products with the originals. The implication of such failure is the damage or the declining of the original mark image. In this point, mark violation, again, brings about injury on behalf the original mark holder.

Despite all the destructive effect of mark violation, it is a cheap shortcut to get market. For those having not enough capital to carry out product research and 
invention to discover innovation, overriding attributed in a well known will be a way in reducing of expenditure that might be vital to survive the existence of the business.

Well known trademarks usually become the main target to be violated and it is very easy to find the false products in the market in much lower price than the original. Such violation ranges from international well known trademark such as Luis Vuiton, Yves Saint Laurent, Gucci or Armani, to local trademark, such as Dagadu.

One interesting factor is the fact that consumers are willing to buy such products, though they know that the products are not the original. The reason is that certain consumers wish to use well known brand product, because the brand will affect the social status of them. Again, the problem we are dealing with here is culture. Further, then the legal question will be: is that considered as trademark violation, since it does lose the distinguishing power? The quick answer is affirmative based on several considerations: first, such act is considered as deliberate and unlawful use of other trademark as referred to in RI Trademark Law (Art. 76 par. 1, 90, 91, and 94).

Second, such use is based on motive to take benefit from the value attached to the original trademark. The benefit in general can be in form of taking the market of the original and therefore get the benefit from the same price as the original (in this case, loss or less distinction ability of the mark, which means that the mark becomes loosing its function or consumer confusion becomes essential), or get benefit from its own market as a result from providing the value of the original trademark on false but much cheaper product (in this case, such confusion of the consumers does not exist, but the consumers take the product to get the image of the original trademark). The case with regard to certain number of violation committed by SME as described above grounds on the last motive.

The nest question then, how to eliminate such violation, when the consumers are still there, queuing in the market to get the false products? Hence, trademark law enforcement will also involve a proper treatment to the consumers.

\section{VIOLATION AGAINST SME TRADEMARK}

In certain cases, though perhaps it is quite rare nowadays, there is possible violation against SME trademark. In Indonesia this issue has been not popular yet, in comparison with the two previous issues. Nevertheless, it is necessary to put further consideration on the potential problems that might emerge with regard to SME trademark protection. As Thomas A. Timberg put:

"The hypothetical case can be illustrated here: a group of SME serves local market and later on a big company also plan to serve the market. The big company use a trademark that is identical with a trademark belongs to the 
SME. This company pretend as such that the SME business has been transferred to the company; therefore, there will be no question or doubt regarding the identical trademark of them."

The other case emerges when a registered trademark of an SME is violated by another SME, such as violation against Dagadu - trademark of T-shirt from Yogyakarta. Instead of objection of the trademark holder, the violation keeps going.

This case will be important to be considered, to attain understanding in the future on the need of SME not only to understand the importance of trademark protection and not to violate other trademarks, but also to be protected with regard to its trademark instead.

\section{CONCLUDING REMARKS}

We have already referred to in the above explanation on the relative merits with regard to trademark law implementation by SME. We have also put emphasize on the significant role of SME in Indonesian economic. Indeed, constant and reliable effort to attain understanding on the characteristics and the needs of SME will be most of all important before taking further step to enforce trademark law. Such effort will involve thorough and conscientious study on economic, social, and legal aspects of SME business.

One considerable factor resulting in the decreasing number of SME registering their trademark is the more high cost procedure. Certain numbers of SME violates trademark law based on particular motive and therefore has particular modus of operandi. And finally it is necessary to be taken into account SME-trademark violation conducted by bigger enterprise; this seems to be out of concern, but cannot be neglected in the effort to build trust on the equal legal protection for all.

The message is hence clear; the need for the general public to respect the essential function of trademark as part of the endeavour to develop SME is not avoidable. Fairly large in amount of SME contribution in Indonesian economic will be best supported with fair business dealing concerning trademark use and thus, the call for the government role to develop more reasonable effort to improve SME in such respect is deemed necessary.

\section{REFERENCES}

Rachmadi Usman, Hukum Hak atas Kekayaan Intelektual: Perlindungan dan Dimensi Hukumnya di Indonesia, Alumni, Bandung, 2003, pp. 331. 
Albert Berry, Edgard Rodriguez, and Henry Sandee, "Firm and Group Dynamics in the Small and Medium Enterprise Sector in Indonesia", in Small Business Economics, Dordrecht: February - May 2002, Vo. 18, ISS. 1-3, pp. 1.

H. Sandee and P. Rietveld, "Innovation Adoption in Rural Industry Clusters: A Comparison of A Roof Tile and Copper Handicraft Cluster in Indonesia", in Ami Sverrson and Meine Pieter van Dijk (eds.), Local Economies in Turmoil: The Effects of Deregulation on Small and Medium Enterprises in Transitional Economies, New York: Macmillan, 2000.

Albert Berry and Brian Levy, "Technical, Financial and Marketing Support for Indonesia's Small and Medium Industrial Exporters", in Brian Levy, Albert Berry and Jeffery B. Nugent (Eds.), Fulfilling the Export Potential of Small and Medioum Firms, Boston: Kluwer, 1999, pp. 50.

The same problem emerges in case of registration and licensing of SME. Only $20 \%$ SME registered and having formal license as reported by Frida Rustiani, "Perizinan Usaha Kecil di Indoesia (Licensing in the Decentralizing Era)", Policy Paper, Partnership for Economic Growth, the Republic of Indonesia Ministry of Industry and Trade, August 20, 2001.

Thomas A. Timberg brings analysis on this matter in "Merek Dagang dan Usaha Kecil di Negara-negara Industri - Bagaimana Usaha Kecil Menggunakannya", loc.cit.

Both the Character Ethic and the Personality Ethic are examples of social paradigms. The word paradigm comes from the Greek. It was originally a scientific term, and is more commonly used today to mean a model, theory, perception, assumption, or frame of reference. In the more general sense, it's the way we "see" the world-not in terms of our visual sense of sight, but in terms of perceiving, understanding, interpreting. 
https://ir.iba.edu.pk/businessreview/vol3/iss2/6

DOI: https://doi.org/10.54784/1990-6587.1152

Business Review - Volume 3 Number 2

July - December 2008

It is futile to argue, as Milton Friedman, the American economist and Nobel Laureate does that a business has only one responsibility: economic performance. Economic performance is the first responsibility of a business. Indeed, a business that does not show a profit at least equal to its cost of capital is irresponsible; it wastes society's resources. Economic performance is the base without which a business cannot discharge any other responsibilities, cannot be a good employee, a good citizen, a good neighbour. But economic performance is not the only responsibility of a business any more than educational performance is the only responsibility of a school or health care the only responsibility of a hospital.

Unless power is balanced by responsibility, it becomes tyranny. Furthermore, without responsibility, power always degenerates into non-performance, and organizations must perform. So the demand for socially responsible organizations will not go away; rather, it will widen.

Peter F. Drucker Managing in a Time of Great Change,p.75 
https://ir.iba.edu.pk/businessreview/vol3/iss2/6

DOI: https://doi.org/10.54784/1990-6587.1152

Business Review - Volume 3 Number 2

July - December 2008 